\title{
Renata Endres**
}

\author{
A. Bryan Endres****
}

\section{TREBA LI SMANJITI ILI POVEĆATI POREZE U TURIZMU?}

\begin{abstract}
Sažetak
Porez na dodanu vrijednost u turizmu ima ključnu ulogu u poticanju razvoja turizma, ostvarivanju konkurentne pozicije turističke destinacije te prikupljanju prihoda ostvarenih od turizma. Dosadašnjom izmjenom visine stopa poreza na dodanu vrijednost u turizmu hrvatska vlada nastojala je ostvariti konkurentnost hrvatske turističke destinacije, uz maksimiziranje iznosa prihoda prikupljenih od turizma. U radu se upotrebljavaju sekundarni podaci za razdoblje od 1998. do 2020., a cilj je rada analizirati alternativan pristup oporezivanju smještaja i ugostiteljstva, sličan onome koji primjenjuje $\mathrm{SAD}$, da bi se ostvarili bolji fiskalni i ekonomski učinci. U rezultatima analize prikazuju se prednosti i nedostaci povišene i snižene stope poreza na dodanu vrijednost u turizmu Hrvatske, odnosno turističkih poreza $\mathrm{SAD}-\mathrm{a}$.

Ključne riječi: javne financije, oporezivanje turizma, konkurentnost, bruto domaći proizvod
\end{abstract}

\section{Uvod}

Uloga poreza na dodatnu vrijednost (PDV-a) u turizmu stalno je aktualna tema jer način oporezivanja znatno utječe na konkurentnost hrvatskog turizma i na ostvarivanje prihoda od turizma. Zabrinjavajuće je što jedna od najnovijih studija stopa PDV-a u turizmu (Zajednica savjetnika, 2018) predviđa $41 \%$ manje investicija i $71 \%$ manje novih zapošljavanja do 2021.

Cilj je članka analizirati dva različita pristupa oporezivanju u turizmu, hrvatski i američki, kako bi se našao optimalan način koji bi pridonio konkurentnosti i kontinuiranom povećanju prihoda od turizma. Kada se govori o očekivanom povećanju prihoda od turizma, fokus je na svim vrstama turizma (boravišni, vikend, izletnički)

\footnotetext{
* dr. sc. Renata Endres, predavač, University of Illinois at Urbana-Champaign, Agricultural and Consumer Economics, Urbana, Illinois, SAD., rendres@illionis.edu

** prof. A. Bryan Endres, dr. iur., University of Illinois at Urbana-Champaign, Agricultural and Consumer Economics, Urbana, Illinois, SAD
} 
i na različitim specifičnim oblicima turizma (kulturni, ekološki, kongresni, nautički, zdravstveni, gastronomski i drugi) ako navedene vrste i oblici turizma uključuju noćenja turista i/ili konzumaciju hrane ili pića u restoranima. Porezni sustavi Hrvatske i SAD-a ne mogu se paralelno uspoređivati jer Hrvatska primjenjuje PDV koji je prihod državnog proračuna, dok SAD primjenjuje porez na promet u trgovini na malo koji je prihod saveznih država i lokalnih jedinica. PDV se obračunava u svakoj fazi proizvodno-prodajnog ciklusa na iznos dodane vrijednosti koja se oblikovala u toj fazi. Porezni obveznik može odbiti PDV koji je platio prethodnom poreznom obvezniku ili ostvariti pravo na povrat plaćenih poreza. Glavna razlika između PDV-a i poreza na promet u maloprodaji u tome je što se PDV ubire u svakoj fazi proizvodnje, dok se porez na promet u trgovini na malo ubire jednokratno, u fazi maloprodaje. Američki sustav opisuje se kako bi se bolje prikazala teorija. U ovome članku nastoji se ukazati na to da je ideju diferenciranja stopa poreza baziranih na elastičnosti potražnje u sustavu poreza na promet u SAD-u vrijedno razmotriti i u sustavu PDV-a.

Glavna hipoteza rada glasi da se povećanjem stope PDV-a ili uvođenjem dodatnog poreza na turizam u destinacijama s visoko neelastičnom potražnjom mogu povećati prihodi. Primjerice, jedan način realizacije predložene ideje koja bi zahtijevala rekonstrukciju sustava PDV-a bio bi da PDV postane zajednički porez države i lokalnih jedinica. Drugi način uključivao bi uvođenje primjene više, tzv. geografske stope PDV-a. Dosad je na razini EU-a bilo dozvoljeno uvođenje samo snižene stope koju bi države članice mogle primijeniti na posebnim, teško dostupnim, područjima i otocima. Drugo rješenje, u skladu s jednom od novijih smjernica MMF-a, bilo bi uvođenje potpuno novog poreza na hotelski smještaj i na usluge restorana u destinacijama s neelastičnom potražnjom (Međunarodni monetarni fond, 2020). Iako navedene predložene promjene najvjerojatnije neće biti moguće realizirati dok ne dođe do oporavka turističkog sektora, prijedlozi se mogu početi razmatrati, posebice jer bi njihovo uvođenje moglo pridonijeti gospodarskom oporavku Hrvatske nakon pandemije bolesti COVID-19.

Analiza koja obuhvaća razdoblje od implementacije PDV-a u turizmu u Hrvatskoj do danas omogućava praćenje dosadašnjih utjecaja promjena poreznih stopa na turističku konkurentnost i prihode. Većina istraživanja ukazuje na potrebu praćenja trenda EU-a pri odlučivanju o iznosu stopa poreza u turizmu. Zemlje članice EU-a snižavaju stope poreza na turističke i ugostiteljske usluge kako bi privukle turiste. Dosadašnja istraživanja ukazuju na to da niže stope PDV-a u turizmu neće negativno utjecati na prihode u dugom roku jer će, kao što je navedeno, stimulirati investicije i povećati konkurentnost. Za razliku od dosadašnjih zaključaka, u ovome se članku objašnjava u kojim bi slučajevima i više stope poreza na smještaj i ugostiteljstvo nastavile privlačiti turiste. Dugoročno snižavanje stopa PDV-a ili niska stopa PDV-a na državnoj razini pridonijeli bi potencijalnom ostvarenju nižih prihoda u određe- 
nim turističkim destinacijama. Taj način razmišljanja bazira se na činjenici da cijene turističke ponude nisu jedini faktor koji utječe na odabir turističke destinacije. Uvažavajući znanstvena istraživanja koja ukazuju na to da bi Hrvatska trebala imati konkurentnu stopu PDV-a u skladu sa svojim okruženjem, u ovome se članku daju preporuke na temelju pozitivnih primjera iz svjetske prakse. Rezultati istraživanja ukazuju na mogućnost ostvarivanja bolje konkurentnosti i prihoda od turizma ako se, uz osnovnu minimalnu stopu poreza u turizmu određenu na državnoj razini, gradovima i općinama omogući da povise tu stopu. Smatra se da bi turističke destinacije $s$ visoko neelastičnom potražnjom uz višu stopu PDV-a u turizmu ili uvođenjem dodatnog poreza na usluge smještaja i restorana mogle ostvariti financijske ciljeve. Višak prihoda od poreza mogle bi: prvo, reinvestirati kako bi stimulirale dolazak većeg broja novih turista (Mak, 1988), drugo, investirati u daljnji razvoj turističke infrastrukture i smanjenje poreznog tereta lokalnih rezidenata te treće, preusmjeriti preostali prihod za ulaganja u manje razvijena turistička područja. Primjerice, grad bi mogao zadržati $90 \%$ dodatnih prihoda od oporezivanja smještaja i ugostiteljstva, a preostalih $10 \%$ dodatnog prihoda mogao bi usmjeriti u državnu blagajnu za ostvarenje planiranih investicija. Na taj bi se način mogla dodatno povećati konkurentnost i ostvariti više prihoda nego samim snižavanjem PDV-a u turizmu na državnoj razini.

U nastavku je opisana organizacija članka. U drugoj cjelini objašnjava se značaj oporezivanja u turizmu. Također, daje se uvid u PDV u turizmu u Hrvatskoj te porez na hotele i restorane u Sjedinjenim Američkim Državama, s posebnim fokusom na saveznu državu Illinois. U trećoj cjelini analizira se utjecaj smanjenja, odnosno povećanja poreza u turizmu Hrvatske na konkurentnost države i prihode od turizma. U četvrtoj cjelini analizira se utjecaj smanjenja, odnosno povećanja poreza u turizmu SAD-a na konkurentnost države i prihode od turizma. Rad se zaključuje u petoj cjelini u kojoj se daju preporuke za hrvatsku fiskalnu politiku, uz razmatranje daljnjih mogućnosti za relevantna istraživanja.

\section{Oporezivanje turizma}

John Tribe, jedan od vodećih autora u području turizma, definira turizam kao privremeni odlazak u destinaciju izvan stalnog mjesta boravka i rada, uz minimalno jedno noćenje, u svrhu odmora, obavljanja posla ili u druge turističke svrhe (Tribe, 2016). Oporezivanje turizma uvijek je aktualna tema jer, unatoč brojnim izmjenama Zakona i Pravilnika o PDV-u, još uvijek nisu utvrđene optimalne stope poreza na usluge smještaja i ugostiteljske usluge. Utvrđivanje optimalnih stopa oporezivanja iznimno je značajno, među ostalim, za konkurentnost hrvatskog turizma, ostvarivanje turističkih prihoda, poticanje zaposlenosti u turizmu, poticanje relevantnih investicijskih ulaganja. U ovoj cjelini daje se kratak pregled poreznih sustava Hrvatske i SAD-a. 
Također se s pomoću sekundarnih podataka iz područja turizma i ugostiteljstva analizira utjecaj smanjenja, odnosno povećanja poreza u turizmu Hrvatske i SAD-a na konkurentnost države i prihode od turizma. U ovom radu detaljno se prikazuje način oporezivanja u državi Illinois. To se ne čini radi usporedbe jer se porez na promet u trgovini na malo, koji se primjenjuje na razini savezne države i lokalnih jedinica, razlikuje od PDV-a koji je državni porez, nego da bi se prikazala varijabilnost unutar porezne nadležnosti. Grad Chicago u državi Illinois međunarodno je važno ekonomsko i turističko središte. Turistička aktivnost u mnogim drugim dijelovima države Illinois gotovo je minimalna. U skladu s time, lokalne vlasti primjenjuju različite stope poreza na turizam unutar pojedine savezne države kako bi maksimizirale prihode uzimajući pritom u obzir razlike u elastičnosti potražnje. Hrvatska ima sličnu geografsku disperziju turističkih i gospodarskih aktivnosti koja bi, teoretski, mogla imati koristi od sličnih varijacija iznosa poreznih stopa. Važno je još jednom naglasiti da se primjer države Illinois ne primjenjuje kako bi se izravno uspoređivali porezni sustavi, već da bi se ilustrirao koncept primjene različite visine poreznih stopa u različitim destinacijama.

\subsection{Porez na dodanu vrijednost u turizmu u Republici Hrvatskoj}

Porezni sustav Republike Hrvatske sastoji se od državnih poreza, županijskih poreza, gradskih ili općinskih poreza, zajedničkih poreza, poreza na dobitke od igara na sreću i naknada na priređivanje igara na sreću i naknada za priređivanje nagradnih igara (Porezna uprava, 2020). PDV je državni porez propisan Zakonom i Pravilnikom o porezu na dodanu vrijednost. U Hrvatskoj se primjenjuje od 1. siječnja 1998. U razdoblju od njegova uvođenja do danas stope PDV-a mijenjale su se nekoliko puta. U fokusu ovoga rada jesu izmjene u sustavu oporezivanja usluga smještaja i ugostiteljskih usluga. Od 1998. način oporezivanja usluga smještaja i ugostiteljskih usluga mijenjao se čak devet puta. U tablici 1 daje se povijesni pregled promjena stopa PDV-a u Hrvatskoj.

Fokusirajući se na promjene stopa PDV-a na usluge smještaja i restorana, u članku se nastoji ukazati kako su te promjene utjecale na sektor turizma i ugostiteljstva. Nakon uvođenja PDV-a u hrvatski porezni sustav 1998. primjenjivala se jedinstvena stopa PDV-a od $22 \%$. Prema mišljenju turističkog sektora, navedena stopa negativno je utjecala na konkurentnost Hrvatske u odnosu na susjedne mediteranske zemlje koje su primjenjivale niže stope PDV-a u turizmu. Bejaković (2016) ističe da je uvođenje PDVa u hrvatski porezni sustav dodatno utjecalo na insolventnost poduzeća u turizmu i hotelijerstvu jer je poduzetnik morao podmiriti poreznu obvezu državi iako još nije naplatio pružanje usluga od hotelskoga gosta ili od turističke agencije. Pokušaj ublažavanja negativnih utjecaja PDV-a na turizam doveo je 1. siječnja 2001. do uvođenja snižene stope PDV-a od 0 \% na usluge organiziranog boravka koje se plaćaju doznakama 
Tablica 1. Evolucija stopa PDV-a u Hrvatskoj s fokusom na smještaj i restorane

\begin{tabular}{|cccccc|}
$\begin{array}{c}\text { Datum } \\
\text { promjene } \\
\text { stope PDV-a }\end{array}$ & $\begin{array}{c}\text { Snižena stopa } \\
\text { PDV-a }\end{array}$ & $\begin{array}{c}\text { Standardna } \\
\text { stopa PDV-a }\end{array}$ & $\begin{array}{c}\text { Stopa PDV-a na } \\
\text { smještaj }\end{array}$ & $\begin{array}{c}\text { Stopa PDV-a na } \\
\text { restorane }\end{array}$ & $\begin{array}{c}\text { Narodne } \\
\text { novine }\end{array}$ \\
\hline 1. 8. 1998. & - & 22 & 22 & 22 & $47 / 95 ; 106 / 96$ \\
\hline 1. 11. 1999. & 0 & 22 & 22 & 22 & $105 / 99$ \\
\hline 1. 1. 2001. & $0 / 10$ & 22 & 22 & 22 & $73 / 00$ \\
\hline 1. 1. 2006. & $0 / 10$ & 22 & 10 & 22 & $90 / 05$ \\
\hline 1. 8. 2009. & $0 / 10$ & 23 & 10 & 23 & $94 / 09$ \\
\hline 1. 3. 2012. & $0 / 10$ & 25 & 10 & 25 & $22 / 12$ \\
\hline 1. 1. 2013. & $5 / 10$ & 25 & 10 & 10 & $22 / 12 ; 73 / 13$ \\
\hline 1. 1. 2014. & $5 / 13$ & 25 & 13 & 13 & $148 / 13$ \\
\hline 1. 1. 2017. & $5 / 13$ & 25 & 13 & 25 & $115 / 16$ \\
\hline 1. 1. 2020. & $5 / 13$ & 25 & 13 & 13 & $121 / 19$ \\
\hline
\end{tabular}

Izvor: European Commission (2019); Zakon o porezu na dodanu vrijednost (NN 47/95; 106/96; 105/99; 73/00; 90/05; 94/09; 22/12; 73/13; 148/13; 115/16; 121/19).

iz inozemstva. Kako bi se dodatno poboljšala turistička pozicija Hrvatske u odnosu na konkurente, 1. siječnja 2006. uvodi se snižena stopa PDV-a od $10 \%$ na usluge smještaja ili smještaja s doručkom, polupansiona ili punog pansiona u svim vrstama komercijalnih ugostiteljskih objekata te na usluge agencijske provizije za navedene usluge. Uvođenje stope PDV-a od $10 \%$ omogućilo je otvaranje novih radnih mjesta, porast ulaganja u ugostiteljski sektor i snižavanje cijena turističkih usluga. Problem koji je i dalje postojao odnosio se na selektivnu primjenu snižene stope PDV-a u turizmu. Navedeni problem uzrokovao je nezadovoljstvo Turističkog poslovnog vijeća pri HGK-u koje je predlagalo snižavanje stope PDV-a i u ugostiteljskoj djelatnosti kako bi se izbjeglo jačanje sivog tržišta. Niža stopa PDV-a u ugostiteljstvu u iznosu od 10 \% uvedena je tek 2013., a 2014. povišena je na $13 \%$. Dio stručnjaka i ugostiteljski poduzetnici smatrali su da su primjena stope PDV-a od $13 \%$ i uvođenje fiskalizacije doprinijeli legalnom poslovanju ugostiteljskog sektora i povećanju prihoda. Drugi dio stručnjaka i Ministarstvo financija tvrdili su da je snižavanje stope PDV-a negativno utjecalo na porezne prihode, a nisu se realizirali ni svi očekivani učinci u ugostiteljskoj djelatnosti. Ponovno povišenje stope PDV-a na $25 \%$ na ugostiteljske usluge 1. siječnja 2017., uz zadržavanje primjene stope PDV-a od $13 \%$ na usluge smještaja, očekivano je rezultiralo burnim reakcijama ugostitelja. Ugostitelji su se žalili da su svi njihovi ulazni troškovi u zadnjih deset godina porasli za najmanje $50 \%$, dok je cijena hrane i pića ostala otprilike ista. Zalagali su se za ponovno snižavanje stope PDV-a na ugostiteljske usluge do razine koja bi im omogućila konkurentno poslovanje u odnosu na susjedne zemlje, što je 1. siječnja 2020. dovelo do snižavanja stope PDV-a s $25 \%$ na $13 \%$. Očekuje se da bi stope PDV-a koje se trenutačno primjenjuju na usluge smještaja i restorana trebale potaknuti ulaganja u turističku infrastrukturu, povećati zaposlenost u hotelijerstvu i ugostiteljstvu te 
povećati zaposlenost u turističkom sektoru, što bi u konačnici trebalo pomoći ekonomskom oporavku države od posljedica pandemije bolesti COVID-19. Nadalje, potencijalno uvođenje inovativnih mjera koje se predlažu u ovom radu, odnosno viših stopa PDV-a ili novog poreza na usluge smještaja i restorana u destinacijama s visoko neelastičnom potražnjom, moglo bi pridonijeti ostvarenju većih prihoda te rastu BDP-a.

\subsection{Turistički porezi u američkoj saveznoj državi Illinois}

SAD ima porezni sustav s više nadležnosti. Federalni porezi i porezi saveznih država nezavisni su te svaka razina vlasti ima ovlasti postavljati vlastite porezne stope i određivati predmete oporezivanja. Nadalje, svaka savezna država ima zaseban porezni sustav neovisan o ostalim saveznim državama. U određenoj saveznoj državi druge jedinice vlasti, kao što su gradovi ili općine, mogu implementirati vlastite poreze. Rezultat toga jest složeni porezni sustav sa znatnim odstupanjima u cijeloj zemlji.

Ne postoji opći porez na promet ili PDV na nacionalnoj razini. Četrdeset pet saveznih država nameće neki oblik poreza na promet proizvoda i/ili usluga. Kad je riječ o porezu na promet, većina saveznih država uspostavlja osnovnu stopu poreza na promet, a zatim lokalnim razinama vlasti, kao što su gradovi, dopušta nametanje dodatnog poreza na promet čiji prihodi idu izravno u tijelo lokalne uprave. Postojeći sustav poreza na promet dodatno komplicira različito oporezivanje predmeta koji podliježu porezu.

Zadnjih godina savezne države i gradovi istraživali su još jedan izvor prihoda porez na hotelske sobe. Navedeni porez najprije su implementirali turistički resorti s namjerom oporezivanja turista od kojih većina nije lokalno stanovništvo te skupljanja prihoda na lokalnoj razini (Collins i Stephenson, 2018). Neke savezne države SAD-a propisuju minimalnu i maksimalnu stopu poreza na hotelsku sobu ako ga gradovi u tim državama odluče implementirati. Samo jedna savezna država, Nevada, propisuje obvezno uvođenje poreza na hotelsku sobu s minimalnom i maksimalnom stopom poreza. Ugostiteljske usluge u SAD-u također se oporezuju na razini saveznih država i na gradskoj razini, uz veliku varijaciju stopa unutar saveznih država i gradova.

\section{Utjecaj smanjenja/povećanja poreza u turizmu Hrvatske na konkurentnost države i prihode od turizma}

Promjene u visini stopa PDV-a u turizmu utječu na konkurentnu poziciju Hrvatske u odnosu na susjedne turističke destinacije te na prihode ostvarene od turizma. Dosadašnja istraživanja ukazuju na potrebu snižavanja stope PDV-a u turizmu (Dombrovski i Hodžić, 2010; Zajednica savjetnika, 2018; Klarić Pisačić, Manojlović i Pisačić, 2018) te se kao pozitivni primjeri navode države članice EU-a koje imaju niže stope $\mathrm{PDV}$-a na smještaj i ugostiteljstvo (vidi tablicu 2). Prema odredbama Direktive 2006/112/EZ, standard- 
na stopa PDV-a u državama EU-a ne smije biti niža od $15 \%$. Države mogu primijeniti jednu sniženu stopu ili dvije snižene stope za proizvode i usluge predviđene Direktivom i one ne mogu biti niže od $5 \%$. Iako u pojedinim državama postoje neka odstupanja, Hrvatska poštuje odredbe Direktive 2006/112/EZ. Srednja vrijednost standardne stope PDV-a u EU-u iznosi $21 \%$, na usluge smještaja $10 \%$, a na usluge restorana $14 \%$.

Tablica 2. Pregled standardnih stopa PDV-a, na usluge smještaja i restorana u EU-u

\begin{tabular}{|c|c|c|c|}
\hline Država & Standardna \% & Smještaj \% & Restorani \% \\
\hline Austrija & 20 & 13 & 10 \\
\hline Belgija & 21 & 6 & 12 \\
\hline Bugarska & 20 & 9 & 20 \\
\hline Hrvatska & 25 & 13 & 13 \\
\hline Cipar & 19 & 9 & 9 \\
\hline Češka & 21 & 15 & 15 \\
\hline Danska & 25 & 25 & 25 \\
\hline Estonija & 20 & 9 & 20 \\
\hline Finska & 24 & 10 & 14 \\
\hline Francuska & 20 & 10 & 10 \\
\hline Njemačka & 19 & 7 & 19 \\
\hline Grčka & 24 & 13 & 24 \\
\hline Mađarska & 27 & 18 & 18 \\
\hline Island & 24 & 11 & 11 \\
\hline Irska & 23 & 9 & 9 \\
\hline Italija & 22 & 10 & 10 \\
\hline Latvija & 21 & 12 & 21 \\
\hline Lihtenštajn & 8 & 3,8 & 8 \\
\hline Litva & 21 & 9 & 21 \\
\hline Luksemburg & 17 & 3 & 3 \\
\hline Malta & 18 & 7 & 18 \\
\hline Nizozemska & 21 & 6 & 6 \\
\hline Norveška & 25 & 10 & 25 \\
\hline Poljska & 23 & 8 & 8 \\
\hline Portugal & 23 & 6 & 13 \\
\hline Rumunjska & 19 & 9 & 9 \\
\hline Slovačka & 20 & 20 & 20 \\
\hline Slovenija & 22 & 9,5 & 9,5 \\
\hline Španjolska & 21 & 10 & 10 \\
\hline Švedska & 25 & 12 & 12 \\
\hline Švicarska & 8 & 3,8 & 8 \\
\hline Turska & 18 & 8 & 8 \\
\hline Ujedinjeno Kraljevstvo & 20 & 20 & 20 \\
\hline
\end{tabular}

Izvor: HOTREC (2017); Zakon o porezu na dodanu vrijednost (2020). 
Copenhagen Economics (2007) potiče na oprez u EU-u pri snižavanju stopa PDV-a u odabranim gospodarskim sektorima zbog potencijalnog narušavanja trgovinskih odnosa između država članica EU-a. Međutim, u nekim sektorima gospodarstva, posebno kad je riječ o lokalnoj isporuci robe i pružanju usluga, prekogranični su učinci ograničeni zbog niskog stupnja supstitucije. Iako različite stope PDV-a za hotele i restorane mogu utjecati na raspodjelu turizma među državama članicama u pograničnim regijama, njihov stvarni utjecaj može biti mali, ovisno o jedinstvenim značajkama turističke destinacije koje se oporezuje nestandardnom stopom (Copenhagen, 2007). U skladu s time, izmjenama i dopunama Direktive o PDV-u iz 2009. odobrene su snižene stope za hotele, druge turističke smještajne jedinice, restorane i ugostiteljske usluge (Direktiva Vijeća, 2009). Samo su dvije države članice EU-a (Danska, Slovačka) i Ujedinjeno Kraljevstvo održavali stope PDV-a za smještaj i restorane prema odgovarajućim standardnim stopama. Zabrinutost Vijeća EU-a u vezi s nestandardnim stopama PDV-a u EU-u uzrokovana je potencijalnim negativnim učinkom koje različite visine stopa PDV-a mogu imati na funkcioniranje unutarnjeg tržišta EU-a (Direktiva Vijeća, 2006). Stopa PDV-a koja je znatno niža od standardne stope u nekim bi državama članicama mogla preusmjeriti potražnju prema državama EU-a koje su manje porezno opterećene te se zato ne preferira njezina primjena. Nastojanje svih država da maksimiziraju porezne prihode određivanjem optimalnog odnosa između elastičnosti potražnje i visine porezne stope sprečava ih u maksimalnom snižavanju stopa PDV-a (Laffer i Seymour, 1979). S druge strane, slijedi li se taj način razmišljanja, koncept povećanja stope PDV-a ili uvođenja novog poreza imao bi suprotan učinak jer bi prema dosadašnjim iskustvima i predviđanjima koristio onim članicama EU-a koje bi zadržale relativno niže stope PDV-a. Važno je istaknuti da je, kao što je prethodno spomenuto, u uslugama smještaja i restorana utjecaj stopa poreza na funkcioniranje unutarnjeg tržišta minimalan te je zato Vijeće EU-a 2009. državama članicama dozvolilo da i dalje primjenjuju niže stope PDV-a. U ovom članku nastoji se potaknuti rasprava kako bi EU razmotrio davanje dozvole za uvođenje viših, tzv. geografskih, stopa PDV-a u destinacijama s visoko neelastičnom potražnjom. Konkretno, očekuje se da povećanje stope PDV-a na usluge smještaja i restorana ili uvođenje dodatnog poreza na te usluge u najposjećenijim turističkim destinacijama s neelastičnom potražnjom ne bi dovelo do smanjenja turističkih dolazaka te bi pozitivno utjecalo na prihode.

Lokalne samouprave u 18 država članica EU-a primjenjuju poseban porez na smještaj (PricewaterhouseCoopers LLP, 2017). Cijene se mogu odrediti po osobi, po noćenju ili kao postotak cijene sobe. Postoje značajne razlike u stopama poreza među lokalnim samoupravama u državi. Primjerice, lokalne cijene u Portugalu kreću se od 1 EUR do 7 EUR po osobi po noći. Prihod od posebnog poreza na smještaj u većini slučajeva zadržava lokalna samouprava. Neke lokalne samouprave upotrebljavaju 
sredstava za poboljšanja infrastrukture i održavanje turističke destinacije. U Hrvatskoj se, međutim, plaća boravišna pristojba, a prihode od njezine naplate zadržavaju turističke zajednice, a ne vlada.

U sljedećem poglavlju analizira se utjecaj poreza u turizmu SAD-a na konkurentnost pojedine savezne države i prihode od turizma. Prema globalnom indeksu konkurentnosti 4.0 koji obuhvaća 141 gospodarstvo, SAD se nalazi na drugome mjestu, dok je Hrvatska na 63. mjestu (World Economic Forum, 2019). Globalni indeks konkurentnosti 4.0 koji mjeri nacionalnu konkurentnost definiran je kao skup institucija, politika i faktora koji određuju razinu produktivnosti. Cilj je proučiti drugačiji pristup oporezivanju i pozitivne primjere iz američke prakse koji bi se mogli implementirati u hrvatski porezni sustav. Cilj rada nije paralelna usporedba poreznog sustava i konkurentnosti Hrvatske i SAD-a, već istraživanje načina na koji se mogu maksimizirati porezni prihodi od turista koji posjećuju destinacije s neelastičnom potražnjom. Kao što je već navedeno, iako PDV i porez na promet u trgovini na malo nisu isti, oba poreza temelje se na transakcijama, s udjelom poreza koji opterećuje krajnjeg potrošača. Također se nastoji objasniti da turističke destinacije s neelastičnom potražnjom, neovisno o tome gdje se nalaze, mogu pridonijeti povećanju prihoda pojedine države. Primjer Amerike uzima se radi bolje ilustracije teorije, a ne radi usporedbe konkurentnosti dviju država.

\section{Utjecaj smanjenja/povećanja poreza u turizmu SAD-a (Illinois) na konkurentnost države i prihode od turizma}

U ranim empirijskim studijama potvrđeno je da je u turističkim resortima porez na hotelske sobe imao zanemariv utjecaj na prihod hotela, što sugerira da je potražnja visoko neelastična i da je porez gotovo u potpunosti prebačen na turiste, većinom nerezidente (Collins i Stephenson, 2018; Combs i Elledge, 1979; Mak i Nishimura, 1979; Bonham i Gangnes, 1996; Hiemstra i Ismail, 1993). Strategija izvoza poreza (tax exporting) implementacijom poreza na hotele ne može se primijeniti na svim područjima i može nametnuti znatna opterećenja u poslovanju nekih hotela. Izvoz poreza odnosi se na praksu jedne jurisdikcije koja nameće porezne terete stanovnicima druge jurisdikcije. Taj se pojam može odnositi na poreze koji prelaze bilo koju granicu, od gradskih do međunarodnih granica. Primjerice, Collins i Stephenson (2018) analizirali su utjecaj poreza na hotelske sobe u iznosu od pet dolara koji je savezna država Georgija uvela 2015. za plaćanje prometne infrastrukture. Procijenili su da su potrošači platili samo 3,48 dolara poreza, a hoteli su podmirili razliku snižavanjem cijena soba. Učinkovitost strategije izvoza poreza u Georgiji i na Havajima zahtijeva daljnju raspravu. Iako zemljopisno velika savezna država Georgia ( 150000 četvornih kilometara) uključuje neke poznate turističke destinacije, ona se u osnovi razlikuje od 
Havaja i koncentracije resorta koji pokreću ekonomiju otočne savezne države. Primjerice, turizam čini oko 12 \% BDP-a Georgije, a 21 \% BDP-a Havaja. Godine 1990. prihodi od poreza na hotelsku sobu na Havajima iznosili su 82 milijuna dolara, čineći taj porez trećim najvećim izvorom prihoda te savezne države, nakon trošarina i poreza na dohodak (Bonham i Gangnes, 1996). Koristeći se analizom vremenskih serija tijekom 12 godina, Bonham i Gangnes (1996) nisu otkrili statistički značajan utjecaj poreza na hotelsku sobu na Havajima na prihod hotela. Iz toga proizlazi da hotelski porez na Havajima može imati vrlo drugačiji ekonomski učinak nego u neturističkim destinacijama poput Georgije. Collins i Stephenson (2018) te Bonham i Gangnes (1996) ukazuju na to da učinkovitost izvoza tereta poreza na hotelsku sobu nerezidentima može biti funkcija jedinstvenih karakteristika određene turističke destinacije. Primjerice, relativan uspjeh havajskog poreza na hotelsku sobu nije moguće ostvariti u svim ostalim saveznim državama. Analizirajući prosječne američke poreze na hotelsku sobu, Hiemstra i Ismail (2001) otkrili su da su samo $28,4 \%$ poreza platili gosti, dok je hotelska industrija pokrila više od $70 \%$ ukupnog poreznog opterećenja. $\mathrm{Na}$ Slici $1 \mathrm{u}$ nastavku prikazan je teorijski utjecaj dodatnog oporezivanja destinacija s izrazito neelastičnom potražnjom i ponudom. U ovoj situaciji veći dio tereta novog poreza snosit će potrošači (turisti) jer je pomak tražene količine od $\mathrm{Q}_{0}$ do $\mathrm{Q}_{1}$ relativno mali. Uvođenje poreza utječe na relativno veće cijene za potrošače (pomak s $\mathrm{P}_{0}$ na $\mathrm{P}_{1}$ ) i na manje smanjenje prihoda za poduzeće prikazano jediničnim pomakom cijene $\mathrm{S}$ $\mathrm{P}_{0}$ na $\mathrm{P}_{\mathrm{F}}$. Udaljenost između $\mathrm{P}_{1}$ i $\mathrm{P}_{\mathrm{F}}$ prikazuje porez. Porezni prihod označen je osjenčanim područjem dobivenim množenjem poreza po jedinici $\left(\mathrm{P}_{1}-\mathrm{P}_{\mathrm{F}}\right) \mathrm{s}$ količinom, $\mathrm{Q}_{1}$. $S$ druge strane, na slici 2 u nastavku ilustriraju se teorijski učinci povećanja poreza uz elastičniju potražnju. Rezultat je veće smanjenje tražene količine i smanjenje prihoda poduzeća u odnosu na rast potrošačkih cijena.

Slika 1. Povećanje poreza u destinacijama s neelastičnom ponudom i neelastičnom potražnjom

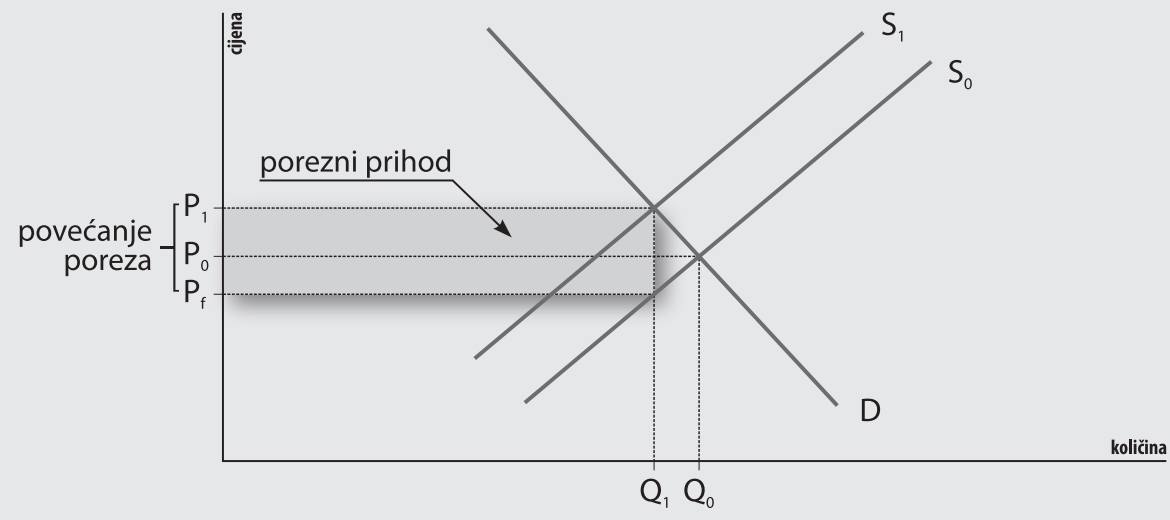


Slika 2. Povećanje poreza u destinacijama s neelastičnom ponudom i elastičnom potražnjom

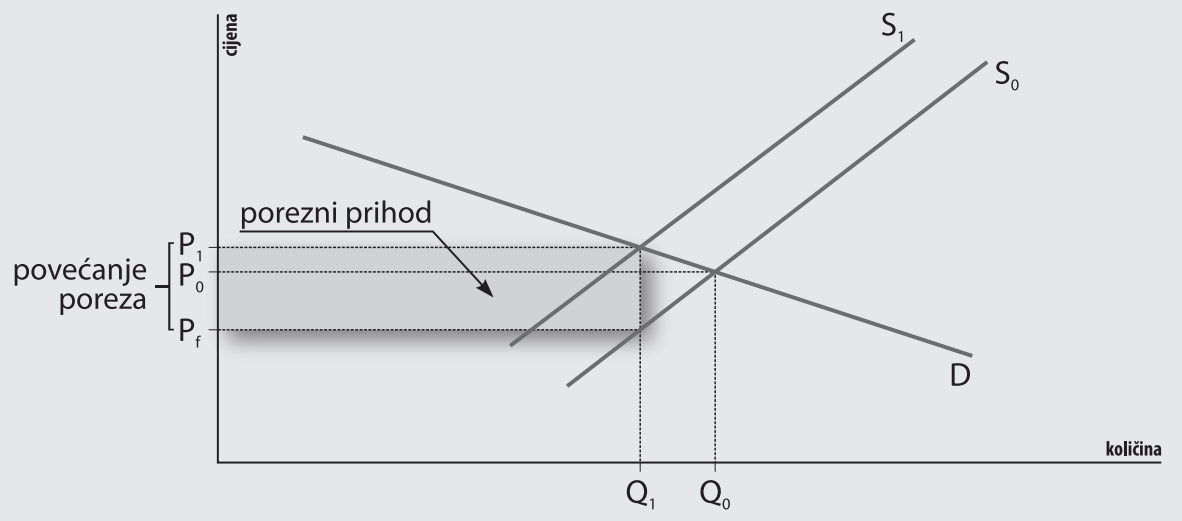

Slika 3. Povećanje poreza u destinacijama s elastičnom ponudom i neelastičnom potražnjom

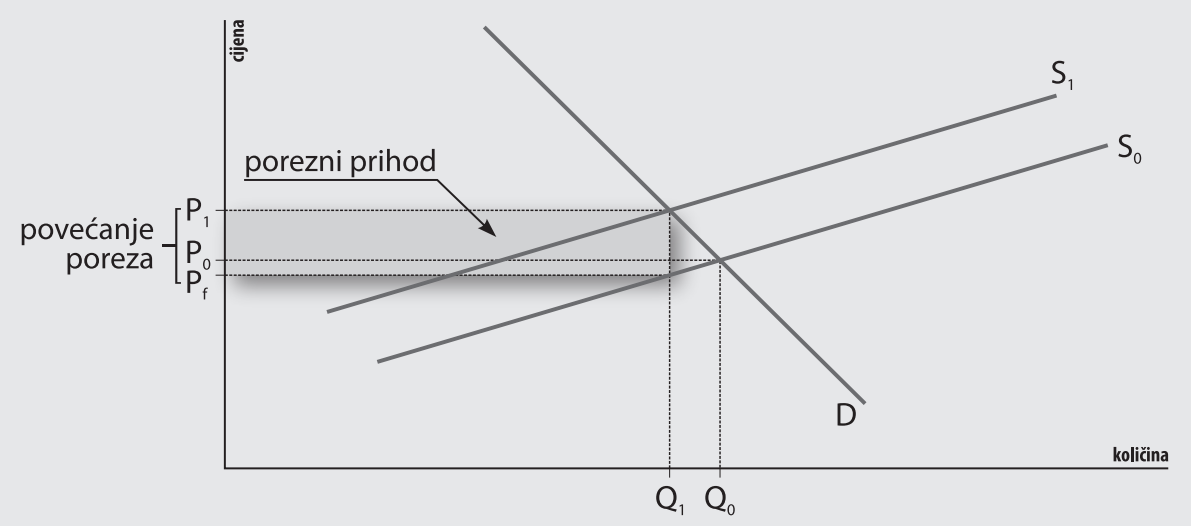

Slika 4. Povećanje poreza u destinacijama s elastičnom ponudom i elastičnom potražnjom

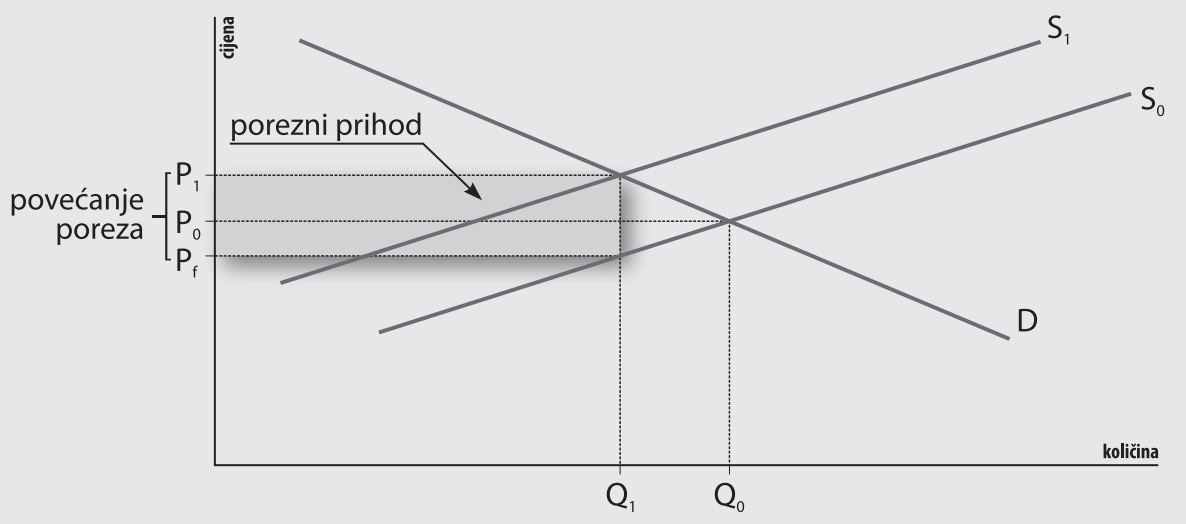

Izvor: autori prema Greenlaw i Taylor (2017). 
Slike 1 i 2 predstavljaju neelastičnu ponudu. Primjerice, broj hotelskih soba uz plažu ili smještaj u određenoj destinaciji relativno je fiksan u kratkom roku pa je stoga ponuda neelastična. Naravno, porast netradicionalnog hotelskog smještaja kao što je Airbnb može povećati elastičnost krivulje ponude za smještaj, što je prikazano na prethodnim slikama 3 i 4 . Za elastičnu ponudu opći učinci jednaki su neelastičnom scenariju u pogledu porezne incidencije i poreznih prihoda. Kao što je prethodno navedeno, sljedeći korak analize jest utvrđivanje elastičnosti potražnje i ponude u odabranim destinacijama, posebno u razdoblju nakon pandemije bolesti COVID-19, prije nego što se krene s preporukama za izmjene poreza.

U tablici 3 navode se porezi na hotele koji se primjenjuju u saveznim državama $\mathrm{u}$ top turističkim destinacijama.

Tablica 3. Porezi na hotele u odabranim saveznim državama

\begin{tabular}{|c|c|c|c|c|}
\hline Država & Porez na promet & Porez na hotele & $\begin{array}{l}\text { Ukupni državni } \\
\text { porez }\end{array}$ & Lokalni porezi \\
\hline Arizona & $n / p$ & $5,5 \%$ & $5,5 \%$ & $\mathrm{Da}$ \\
\hline Kalifornija & $n / p$ & $n / p$ & Nema & $\mathrm{Da}$ \\
\hline Colorado & $2,9 \%$ & $n / p$ & $2,9 \%$ & $\mathrm{Da}$ \\
\hline Florida & $6,0 \%$ & $n / p$ & $6,0 \%$ & $\mathrm{Da}$ \\
\hline Georgia & $4,0 \%$ & $\$ 5$ po sobi & $4,0 \%+\$ 5$ & $\mathrm{Da}$ \\
\hline Havaji & $4,0 \%$ & $10,25 \%$ & $14,25 \%$ & No \\
\hline Illinois & $n / p$ & $6,0 \%$ & $6,0 \%$ & $\mathrm{Da}$ \\
\hline Louisiana & $4,45 \%$ & $n / p$ & $4,45 \%$ & $\mathrm{Da}$ \\
\hline Maryland & $6,0 \%$ & $n / p$ & $6,0 \%$ & $\mathrm{Da}$ \\
\hline Massachusetts & $\mathrm{n} / \mathrm{p}$ & $5,7 \%$ & $5,7 \%$ & $\mathrm{Da}$ \\
\hline Nevada & $n / p$ & $n / p$ & Nema & Obvezan \\
\hline New York & $4,0 \%$ & $n / p$ & $4,0 \%$ & $\mathrm{Da}$ \\
\hline Teksas & $n / p$ & $6,0 \%$ & $6,0 \%$ & $\mathrm{Da}$ \\
\hline Virginia & $4,3 \%$ & $0,0 \%$ & $4,3 \%$ & $\mathrm{Da}$ \\
\hline District of Columbia & $n / p$ & $14,95 \%$ & $14,95 \%$ & $n / p$ \\
\hline
\end{tabular}

Izvor: National Conference of State Legislatures (2019); Illinois General Assembly (2019).

Rješenje za porezno opterećenje koji zahvaća lokalnu hotelsku industriju možda nije napuštanje dosadašnje porezne strategije, već ciljanija primjena na onim lokacijama koje imaju željene turističke karakteristike da održe neelastičniju potražnju. To bi moglo biti na razini savezne države, kao na Havajima, ili na lokalnoj razini, kao u gradovima koji imaju velike turističke atrakcije. Primjerice, Disney World u Orlandu (Florida) nameće $6,5 \%$ općeg poreza na promet i $6 \%$ poreza na hotelsku sobu. 
U sklopu američkog poreznog sustavu s više jurisdikcija, lokalne jedinice vlasti uglavnom imaju mogućnost uvođenja poreza na različite proizvode i usluge neovisno o bilo kojoj državnoj politici (vidi tablicu 4).

Tablica 4. Savezne države koje dopuštaju uvođenje lokalnih poreza na hotelsku sobu i minimalno, odnosno maksimalno dozvoljena stopa poreza

\begin{tabular}{|c|c|c|}
\hline Država & Minimalna stopa & Maksimalna stopa \\
\hline Kalifornija & $n / p$ & $n / p$ \\
\hline Florida & $1 \%$ & $6 \%$ \\
\hline Georgia & $3 \%$ & $8 \%$ \\
\hline Indiana & $n / p$ & $5 \%$ \\
\hline Illinois & $n / p$ & $n / p$ \\
\hline Kansas & $1 \%$ & $8 \%$ \\
\hline Maryland & $n / p$ & $8 \%$ \\
\hline Michigan & $n / p$ & $5 \%$ \\
\hline Minnesota & $n / p$ & $7 \%$ \\
\hline Novi Meksiko & $n / p$ & $5 \%$ \\
\hline New York & $n / p$ & $5 \%(5,8 \%$ u NYC-ju) \\
\hline Sjeverna Karolina & $n / p$ & $n / p$ \\
\hline Sjeverna Dakota & $n / p$ & $3 \%$ \\
\hline Ohio & $n / p$ & $7 \%$ \\
\hline Oklahoma & $n / p$ & $5 \%$ \\
\hline Tennessee & $n / p$ & $6 \%$ \\
\hline Virginia & $n / p$ & 2 \% (5 \% u nekim područjima) \\
\hline Washington & $1 \%$ & 5,8 \% (7 \% u Seattleu) \\
\hline Zapadna Virginia & $3 \%$ & $6 \%$ \\
\hline Wisconsin & $n / p$ & $8 \%$ \\
\hline Wyoming & $1 \%$ & $4 \%$ \\
\hline
\end{tabular}

Izvor: Illinois General Assembly (2019).

Primjerice, država Illinois nameće porez od $6 \%$ na bruto prihod od hotelskih soba (vidi tablicu 3). Na poboljšanje državne infrastrukture odlazi $40 \%$ poreznih prihoda, a preostalih $60 \%$ odlazi na promociju turizma (Illinois General Assembly, 2019). Chicago, međunarodna turistička i poslovna destinacija, nameće različite dodatne poreze na hotelsku sobu povećavajući stopu na 17,58 \% (Illinois General Assembly, 2019). Iznajmljivanje dijela kuće, npr. na platformi Airbnb, u Chicagu se oporezuje porezom na sobu u iznosu od 23,4 \% (The Civic Federation, 2019). Mnogo manji gradovi u državi Illinois, kao što su Urbana i Champaign, dva grada koja graniče s najvećim državnim sveučilištem, uvode dodatni porez od $7 \%$, čime se stvarna stopa poreza povećava na $13 \%$. Sveučilišni gradovi Urbana i Champaign značajne su turističke destinacije jer se u njima organiziraju brojni sportski i kulturni događaji te se 
stoga na neki način mogu usporediti s prethodno navedenim primjerima Orlanda i Floride. S druge strane, ostali gradovi u državi Illinois, za koje ne postoji značajnija poslovna ili turistička potražnja, uveli su značajno niže stope poreza na hotelske sobe (vidi tablicu 5).

Tablica 5. Stope poreza na hotele u većim gradovima u državi Illinois

\begin{tabular}{cc} 
Grad & Stopa \\
\hline Bloomington/Normal & $12 \%$ \\
\hline Champaign/Urbana & $\mathbf{1 3} \%$ \\
Chicago & $17,4 \%$ \\
Galesburg & $16,8 \%$ \\
\hline Peoria & $14 \%$ \\
\hline Springfield & $13 \%$ \\
\hline
\end{tabular}

Izvor: Illinois Department of Central Management Services (2019).

Ugostiteljske usluge u SAD-u oporezuju se na razini saveznih država i na gradskoj razini, ali stope poreza u velikoj mjeri variraju u saveznim državama i gradovima (vidi tablicu 6).

Tablica 6. Stope poreza na hranu i piće u restoranima u odabranim gradovima u saveznoj državi Illinois

\begin{tabular}{|c|c|c|c|c|}
\hline & Chicago & Naperville & Urbana & Bloomingtor \\
\hline $\begin{array}{c}\text { Državni opći porez na } \\
\text { promet }\end{array}$ & $6,25 \%$ & $6,25 \%$ & $6,25 \%$ & $6,25 \%$ \\
\hline $\begin{array}{c}\text { Općinski opći porez na } \\
\text { promet }\end{array}$ & $1,75 \%$ & $0,75 \%$ & $1,25 \%$ & $0,0 \%$ \\
\hline $\begin{array}{l}\text { Prijevozno tijelo } \\
\text {,Transportation Authority' }\end{array}$ & $1,0 \%$ & $0,75 \%$ & $n / p$ & $n / p$ \\
\hline $\begin{array}{c}\text { Gradski opći porez na } \\
\text { promet }\end{array}$ & $1,25 \%$ & $0,75 \%$ & $1,5 \%$ & $2,5 \%$ \\
\hline $\begin{array}{l}\text { Gradski porez na hranu i } \\
\text { piće }\end{array}$ & $0,5 \% *$ & $1,0 \% * *$ & $1,5 \%$ & $2,0 \%$ \\
\hline Ukupno & $10,75 \%$ & $9,5 \%$ & $10,5 \%$ & $10,75 \%$ \\
\hline \multicolumn{5}{|c|}{$\begin{array}{l}{ }^{*} \text { Chicago na sve restorane primjenjuje stopu poreza od 0,5 \% i dodatnu stopu od 1,0 \% na } \\
\text { restorane u centru. } \\
{ }^{* *} \text { Naperville na sve restorane primjenjuje stopu poreza od } 1 \% \text { i dodatnu stopu od 0,75 \% na } \\
\text { restorane u centru. }\end{array}$} \\
\hline
\end{tabular}

Izvor: Illinois General Assembly (2019).

Ukratko, svaka jedinica lokalne samouprave mora odlučiti o optimalnoj poreznoj stopi koja omogućuje ostvarivanje ravnoteže između prihoda od poreza ostvarenih na lokalnoj razini od nerezidenata i potencijalnih gubitaka poslovanja hotela zbog susjednih kompetitivnih gradova ili regija. 


\section{Zaključak i preporuke}

Konvencionalna je mudrost da iznos stope PDV-a treba biti jednak u svim regijama države (Embrill et al., 2001). Postoje, međutim, izuzeci. Primjerice, u EU-u člankom 120 Direktive o PDV-u ovlašćuje se Grčku da za određene lokacije snizi stope PDV-a do 30 \% (Direktiva Vijeća, 2006). Jedinstveni aspekt prijedloga ovog rada za razmatranje i daljnje empirijsko vrednovanje kombinacija je predlaganja viših umjesto nižih stopa PDV-a, kakav je dosad bio slučaj, i omogućavanje geografske diversifikacije u pojedinoj državi EU-a. Samo bi nekoliko lokacija s izrazito neelastičnom potražnjom imalo koristi od povećanih stopa, dok bi područja s elastičnom (ili manje neelastičnom) potražnjom zadržala standardnu stopu. Ideja je omogućiti vladama da urede poreznu politiku tako da maksimiziraju prihode u destinacijama s neelastičnom potražnjom. Ta dodatna sredstva mogu dalje uložiti u infrastrukturu ili druga javna dobra. Naravno, PDV je porez na nacionalnoj razini. No, u skladu s načelom supsidijarnosti iz članka 5 Ugovora o Europskoj uniji, odluke se, ako je to moguće, trebaju donositi na najnižoj razini vlasti. U skladu s time, lokalne samouprave mogle bi procijeniti elastičnost potražnje za svoje mjesto i od vlade zatražiti da povisi stopu PDV-a ako se radi o mjestu s neelastičnom potražnjom. U idealnom slučaju, dodatni porezni prihodi vratili bi se lokalnoj vlasti radi daljnjih ulaganja u usluge za stanovnike i infrastrukturu koja bi podržala dodatni gospodarski rast, uključujući turizam. U situacijama kada nije moguće uvesti više, tzv. geografske stope PDV-a, neposrednija opcija mogu biti posebni transakcijski porezi na hotele, smještaj i restorane (Međunarodni monetarni fond, 2020).

Hrvatska sa svojom jakom turističkom potražnjom u specifičnim, nezamjenjivim mjestima pruža priliku za inoviranje ili barem daljnje proučavanje ekonomije tog novog pristupa. Primjer oporezivanja hotela na Havajima višom stopom poreza na hotele ukazuje na to da dugoročna konkurentnost, kao ni prihodi od turizma, neće izgubiti na značaju u gradovima koji su najjače turističke destinacije. Ti gradovi svojom kvalitetom sadržaja i prirodnim atrakcijama mogu održati konkurentnost i uz povećanje stope PDV-a. Nadalje, ti bi gradovi uz povećane prihode mogli ostvariti dodatne investicije, povećati zaposlenost te višak sredstava uložiti u manje razvijene gradove ili općine. $\mathrm{Na}$ taj bi se način povećale investicije u manje razvijenim dijelovima $\mathrm{Hr}$ vatske, povećala bi se zaposlenost te bi se, uz inoviranje turističke ponude, privukao i veći broj turista. Kontinuirano snižavanje turističkih poreza kao način zadržavanja i privlačenja turista iz drugih lokacija može rezultirati „utrkom do dna” jer će smanjenje poreza koje implementira jedno porezno tijelo pokrenuti naknadna smanjenja koja će implementirati druga porezna tijela, što će rezultirati time da će prvo porezno tijelo dodatno smanjiti porez i tako dalje. Takav pristup u Hrvatskoj može rezultirati potencijalnim gubitkom prihoda gradova ili regija s visoko neelastičnom potražnjom. 
Dopuštanje međugradske varijabilnosti u stopama turističkih poreza moglo bi vratiti inače izgubljeni prihod. U regijama u kojima hotelijeri cjelokupni porezni teret ne mogu prebaciti na turiste, porezna vlast svejedno bi mogla nametnuti lokalne poreze iznad nacionalnog minimuma te nadoknaditi ekonomski gubitak hotelske industrije usmjeravanjem određenog dijela prihoda od poreza na hotele na promicanje lokalnog turizma (Mak, 1988). Korištenje dijela poreznih prihoda prikupljenih od poreza na hotele za povećanje turističke promocije može smanjiti negativan utjecaj poreza na turističku potražnju te također smanjiti prigovore hotelijera zbog uvođenja dodatnih poreza na hotele. Pri analizi učinka PDV-a na smještaj i ugostiteljstvo u Hrvatskoj, potrebno je u obzir uzeti i druge relevantne vanjske čimbenike koji mogu utjecati na potražnju, konkurentnost i prihode. Ukratko, viša stopa PDV-a na smještaj i ugostiteljstvo ne mora nužno značiti i pad konkurentnosti i prihoda ako drugi čimbenici imaju značajniji utjecaj na potražnju. Najnoviji podaci Ministarstva turizma (2019) prikazuju da broj noćenja u top pet destinacija u Hrvatskoj (Krk, Dubrovnik, Rovinj, Poreč, Pag) čini 20,25 \% ukupnih noćenja u zemlji (Ministarstvo turizma Republike Hrvatske, 2019). Ako bi u navedenim lokacijama postojala neelastična potražnja, tada bi i malo povećanje porezne stope na usluge smještaja moglo donijeti znatan prihod. Turistička percepcija jedinstvenosti turističke destinacije, a samim time i elastičnost potražnje, može se vremenom mijenjati pa je prije implementacije bilo kakvih dodatnih poreza ključno procijeniti elastičnost ne samo na temelju povijesnih podataka, već i u razdoblju nakon pandemije bolesti COVID19 (PricewaterhouseCoopers, 2017). Zatim je potrebno empirijski ispitati koji bi iznos stope poreza maksimizirao prihode u destinaciji s neelastičnom potražnjom. Nakon provedenog istraživanja mogla bi se razmotriti potencijalna implementacija predloženih mjera. U ovome članku predstavljena je inovativna ideja o oporezivanju usluga smještaja i restorana. Hrvatska u nekim turističkim destinacijama ima izrazito neelastičnu potražnju te ima predispozicije da bude inovator porezne politike na području EU-a i šire umjesto da samo slijedi primjere drugih. 


\section{Literatura}

1. Bejaković, P. 2016. Promjene poreza na dodanu vrijednost u Hrvatskoj u novom tisućljeću. Porezni vjesnik, 9: 153-162.

2. Benedek, D., De Mooij, R., Keen, M. i Wingender, P. 2015. Estimating VAT Pass Through. IMF Working Papers, 15 (214): 1. https://www.imf.org/en/Publications/WP/ Issues/2016/12/31/Estimating-VAT-Pass-Through-43322. 23. travnja 2020.

3. Bluestein, G. 2015. Georgia's hotel industry fights new $\$ 5$ fees. Atlanta Journal Constitutional, April 24.

4. Bonham, C. S. i Gangnes, B. 1996. Intervention analysis with cointegrated time series: the case study of the Hawaii hotel room tax. Applied Economics, 28 (10): 1281-1293.

5. Collins, C. G. i Stephenson, E. F. 2018. Taxing the Travelers: A Note on Hotel Tax Incidence. Journal of Regional Analysis and Policy, 48: 7-11.

6. Combs, J. P. i Elledge, B. 1979. Effects of Rom Tax on Resort Hotels/Motels. National Tax Journal, 32: 210-207.

7. Copenhagen Economics. 2007. Study on reduced VAT applied to good and services in the Member States of the European Union. https://ec.europa.eu/taxation_customs/sites/taxation/files/resources/documents/taxation/vat/how_vat_works/rates/study_reduced_vat. pdf. 24. travnja 2020.

8. Direktiva Vijeća 2006/112/EZ od 28. studenoga 2006. o zajedničkom sustavu poreza na dodanu vrijednost. 2006. SL L 347: 1-118. https://eur-lex.europa.eu/legal-content/HR/ TXT/?uri=celex\%3A32006L0112. 25. travnja 2020.

9. Direktiva Vijeća 2009/47/EZ od 5. svibnja 2009. o izmjeni Direktive 2006/112/EZ o sniženim stopama poreza na dodanu vrijednost. 2009. SL L 116: 18-20. https://eur-lex.europa.eu/legal-content/HR/TXT/PDF/?uri=CELEX:32009L0047\&qid=1588141835328\& from=HR 25. travnja 2020.

10. Davis L. W. 2011. The Effects of Preferential VAT Rates Near International Borders: Evidence from Mexico. National Tax Journal, 64 (1): 85-104.

11. Dombrovski, R. i Hodžić, S. 2010. Impact of Value Added Tax on Tourism. International Business and Economics Research Journal, 9 (2): 131-138.

12. Embrill, L., Keen, M., Bodin, J. i Summers, V. 2001. The Modern VAT. International Monetary Fund. Washington, D. C.

13. European Commission. 2019. VAT rates applied in the Member States of the EU. https:// ec.europa.eu/taxation_customs/sites/taxation/files/resources/documents/taxation/vat/ how_vat_works/rates/vat_rates_en.pdf. 25. travnja 2020.

14. Greenlaw, S. i Taylor, T. 2017. Principles of Economics. Openstax, Rice University, Houston, USA.

15. Hiemstra, S. J. i Ismail, J. A. 2001. Research Note to 'Incidence of the Impacts of Room Taxes on the Lodging Industry': Revision to Article Published in Spring 1993 Issue of JTR. Journal of Travel Research, 39: 319-320.

16. HOTREC. 2017. Report on the benefits of low VAT on job creation and competitiveness in the European Union. http://net-tourism.eu/images/HOTREC_VAT_report_-_May_2017. pdf. 10. studenog 2019.

17. Illinois Department of Revenue. 2019. Annual Report. https://www2.illinois.gov/rev/ research/taxstats/AnnualCollectionsDistributions/Documents/FY19_Annual_Report. pdf. 27. travnja 2020.

18. Illinois General Assembly, Commission on Government Forecasting and Accountability. 2019. Illinois Tax Handbook for Legislators ( $35^{\text {th }}$ Edition). 
19. International Monetary Fund. 2020. Tax Policy Assessment Framework: Value-Added Tax. https://www.imf.org/external/np/fad/tpaf/tpaf_home.htm. 24. travnja 2020.

20. Klarić Pisačić, M., Manojlović, N. i Pisačić, M. 2018. Promjene stope PDV-a i pokazatelji profitabilnosti u ugostiteljstvu. Obrazovanje za poduzetništvo, 8 (4): 25-40.

21. Laffer, A. B. i Seymour, J. P., ur. 1979. The economics of the tax revolt: A reader. New York.

22. Mak, J. i Nishimura, E. 1979. The Economics of a Hotel Room Tax. Journal of Travel Research, 17 (4): 2-6.

23. Mak, J. 1988. Taxing Hotel Room Rentals in the U. S. Journal of Travel Research, 27 (1): $10-15$.

24. Ministarstvo turizma Republike Hrvatske. 2019. Turizam u brojkama. https://mint.gov. hr/UserDocsImages/AA_2018_c-dokumenti/190614_HTZ\%20TUB_2018_hrv.pdf. 24. travnja 2020.

25. Porezna uprava. 2020. Porezni sustav Republike Hrvatske. https://www.porezna-uprava. hr/HR_porezni_sustav/Stranice/naslovna_tablica_psrh.aspx. 23. travnja 2020.

26. Pravilnik o porezu na dodanu vrijednost. NN 79/13, 85/13 - ispr., 160/13, 35/14, 157/14, 130/15,1/17, 41/17, 128/17, 1/19.

27. PricewaterhouseCoopers LLP. 2017. The Impact of Taxes on the Competitiveness of European Tourism, Final Report. Directorate-General for Internal Market, Industry, Entrepreneurship and SMEs, EUR 2017.5998 EN.

28. The Civic Federation. 2019. How do Chicago's Hotel and Home Share Taxes Compare to Other Cities? https://www.civicfed.org/civic-federation/blog/how-do-chicagos-hoteland-home-share-taxes-compare-other-cities. 20. studenog 2019.

29. Tribe, J. 2016. The Economics of Recreation, Leisure and Tourism. Fifth Edition. Routledge. New York.

30. World Economic Forum. 2019. The Global Competitiveness Report. http://www3.weforum.org/docs/WEF_TheGlobalCompetitivenessReport2019.pdf.

31. Zajednica savjetnika. 2018. Analiza utjecaja stope PDV-a na konkurentnost smještaja $i$ ugostiteljstva Hrvatske. https://www.hgk.hr/documents/hgkanaliza-pdv-smjestaj-ugostiteljstvo5a7dc017053b5.pdf. 10. listopada 2019.

32. Zakon o porezu na dodanu vrijednost. NN 47/95; 106/96; 105/99; 73/00; 90/05; 94/09; 22/12; 73/13; 148/13; 115/16; 121/19. 


\section{Whether to decrease or increase taxes in tourism}

\section{Abstract}

Value added tax in tourism has a key role in stimulating tourism development, improving competitiveness and generating revenue. The Croatian government has periodically adjusted the value added tax rate in tourism in an attempt to increase the country's tourism competitiveness while maximizing revenues. Using secondary data from 1998 to 2020, the aim of this paper is to analyze an alternative approach, more similar to the tax policy principles applied in the USA, to achieve improved fiscal and economic output. The results of the analysis show the advantages and disadvantages of increased and reduced value added tax rate on tourism in Croatia and tourism taxes in the USA.

Key words: Public finances, tourism taxation, competitiveness, gross domestic product 